\title{
국제 항결핵회의 참관기(22차 IUTA)
}

이화여자 대학교 흥곽내과

이 기 용

국제항결핵연맹 (IUAT)는 회원국이 약 80여 국가이 며 제 22 차 회의는 일본 동경 뉴오다니 호텔에서 1973 년 9월 24일부터 28일까지 개최되었다. 처음에 개회식 을 시마즈 다다즈구 회장의 개회사에 이어 제 22 회 국 제결핵회의 조직위원장(이시자끼 타이즈)이 신병으로 참석하지 못하여 결핵예 방 협회장이 환영사를 대리하 였으며 축사는 지지부노 미야 건하 후생대신 마이도, 동경도 지사 미노베, $\mathrm{WHO}$ 사무총장을 대리하여 결핵 과장 Dr.K. L.히체의 축사로. 끝을 마친다음 메세지 는 국제결핵예 방 연합사무총장 (부에루나루)을 대리하 여 Dr. Tomson이 낭독하고 개회식을 라치었다.

이 개회식에 참석한 최 원국은 72 국가이며 비회원국 참가수는 12 개국이었다. 회의 에 참가한 국가중에 우리 나라 대표는 19명이 참가하였으며 북한에서도 4 명이 참가하고 조련계에서도 3 명이 참가하였다. 상기한바와 같이 84 개국가에서 찯가한 대표수는 일본인 656 명 각 국대표 906 명 총 1,560 여명이 참석하였다. 축사를 하 신 분증에 일본의 야마구지씨는 1971 년에 쏘련의 모스 코바에서 제 21 차 국제 항 결핵 연맹희의 당시에 발표된 결핵으로 인하여 사당 및 발생율은 점차적으로 감소되 어가고 있으나 아직까지도 세계인구의 약 3 분의 2 라는 수에 달하는 결핵환자가 고민하고 있다고 말하였다.

(관리) 1. 일본의 결핵현황(Dr. Kakurai)

일본은 1958년부터 국민 사회보험 제도를 만들어 결 핵퇴치를 시작하였고 결핵문제를 십대질병의 하나 로 다루어 왔다고 말하였으며 현재 일본의 결핵환 자수는 약 백만명이라고 하며 전체 질병의 10 위를 차 지하고 있으며 일본 총인구의 $1.5 \%$ 를 결핵환자가 차 지하고 있다. 국제적으로 결핵이 박멸되었다고 말하려 먼 유병율이 총인구에 비교하여 $1 \%$ 영하로 감소되어야 한다. 현재와 같이 일본의 결핵유병율이 감소된 이유 는 보험제도 및 공중위생을 철저히 관리하고 효과적인 치로방법울 써왔기 때문이라고 한다.
2. 경제 사회발전의 새 방향과 보건대책 “심포지음․ (Dr. Ruderman. Canada)

사회 경제발전을 위하여 투자를 하려면 투자에 대한. 어떤 이득이 생기는데 보건관리 사업에 투자틀 하뎐그 러한 현상을 찾아볼수 없으며 따라서 대자본을 보건사 업에 투자하려들지 않는다. 그러나 보건사업예 종사하. 는 사람은 국민의 건강관리를 위하여 이윤은 없으누 복지사회를 위하여 투자가 필요하다고 강조하고 이를 지적하였다.

\section{3. 결핵관리를 기획하고 조사연구하여 사업을 평가} 하기 위한 역학적 지침 “심포지음” (Dr. Styblo)

질병을 연구조사하고 기획하려면 지표(Index)가 있 는데 즉 사망울, 이환율, 감염발생울 등이다. 결핵의 전염율이 높은것은 $6 \%, 3 \% 15 \%$ 등을 말하고 적은것은 $0,75 \%$ 이하들을 말한다. 세계 각 국가들은 상이한 결 핵간리 방법을 하고있고 또한 서로 상이한 평가방법을 쓰고있다. 이러한 평가기 준은 결핵의 원균인 감염율을 조기발견하고 치료상황, 치룍중단 또는 객담검사 후에 처음으로 진단이 되는 경우등에 있어서도 적용이된다.

\section{(세균) 1 . 결핵균에 항산성의 본태에 관한연구 (Dr. Nyka U.S.A)}

(1) 염색된 결핵규(Carbol-fuchsin)이 acid alcohol에 탈색되지 않고 resistant한 것은 active oxigen때 문이다.

(2) mycobacteria의 acid fastness는 oxigen reduction과 깊은 관계가 있다.

(3) mycobacteria내의 산소의 존재는 fastness의 하. 나인 facter가 된다.

2. 사람의 혈청, 적혈구, 그리고 폐조직에 있어서의 Ethambutol (EMB) Level에 비교연구(Dr. Urovic, France) 
결핵 및 호흡기질환 Vol. 21, No. 2. April 1974

24 명 환자에게 $\mathrm{EMB} 1200 \mathrm{mg}$ 투여하고 $\mathrm{IM}$ 주한 후 1.5 시간, 2.5 시간, 12 시간, 24 시간 $\mathrm{EMB}$ 량을 측정한 결과 혈청 0.6감마 R.B.C. 1감마, 폐조직 7.7감마로 나타났다. 주사후 1 시간에 혈청내보다 폐조직이 10배 높다.

3. 결핵균의 생화학적 특정이 INH 내성에 미치는 영 향(Dr. Boulakbal, 알제리아) INH 0.2감마 또는그 이상의 내성균 1000 주의 효소 실험결과(내성)

(1) Catalase activity, peroxidase test, nitrate test, niacin test etc.은 내성균 및 내성정도 그리고 일차내 성과 획득내성간의 별차없다.

(2) 시험균주의 niacin test negative주는 $37 \%$ 로서 매우높다.

4. 일본 홍부병원에서 1971 1972년까지 비정형 항산 균데 대한연구 (Dr. Tsukamura)

(1) 전결핵균의 $6 \%$ 비정균형

(2) Kansasii는 $0.8 \%$

(3) Scrobulaceum $9.3 \%$ 에서 $0.4 \%$

(4) Intracella는 급격감소.

5. 약제 내성과 측정 조사결과(Dr. Kleebera) 16,500 주(7년간 retrospective analysis)

(1) primary resistance는 $11 \%$.

(2) 지방별로 차이가 있다 $(20 \% \sim 5 \%)$

(3) acquirea resistance는 치료 2 3개월 22\%

(INH 0.2 감마)

" 3 6개 월 $44 \%$
" 7 12개월 $59 \%$
" 1 2 2년 $\quad 72 \%$

(치로) 1. (리팜피신) REP뱅일 또는 간뎔요법 치로 호과(Dr. Aoyagi. Japan)

$\mathrm{REP}+\mathrm{EMB}$ 두가지 약을 매일 투약한 환자와 REP 주 2 회 $+\mathrm{EMB}$ 매일 투약한 결가 두가지 모두 치토호과 가 동등하다고 하며 $\mathrm{REP}$ 며일 $+\mathrm{EMB}$ 주 2 희 투약ㄱ한 결 과 균음전율은 $75.9 \%$ 이고 REP주 2회 $\mathrm{EMB}$ 주2회 투 약 한결과 균음전을 $48.4 \%$ 의 결콰를 나타넜다고 간단 히 보고하였다.

2. 폐결핵 2 차치로제 $\mathrm{REP}$ 와 $\mathrm{EMB}$ 의 간철요법 (Dr. Larbaoul. Aløeria)

(1) 약제 내성이 $\mathrm{REP}$ 가 높게 나타남.

(2) 약 값이 비싼것이 결점

(3) 부작용을 적게해야 한다(독성제거)

(4) $\mathrm{REP}$ 와 2 차약제들을 주 2 회 간헐요법이 가능해야 한다고 보고함.

3. 과거 치료경력이 없는 폐결핵 환자에 대한 INH,리
팜피신 $(\mathrm{REP})$ 에탐부폴, $(\mathrm{EMB})$ 의 단기 치료 (Dr. Burzoni Moroco)

100 명의 균양성 신환자에계 $\mathrm{REP}+\mathrm{EMB}$ 를 매일 2 개 윌간 그후 $\mathrm{INH}$ 단독 또는 $\mathrm{INH}+\mathrm{SM}$ (감톡하에) 주 2회 씩 투여하고 $\mathrm{INH}$ 내성인 경우 $\mathrm{REP}+\mathrm{EMB}$ 를 주 2 회씩 각각 4 개월간 투약하였다. 그 결과에 초치료환자를 $\mathrm{REP}+\mathrm{EMB}$ 매일 2개월 치료후 $\mathrm{REP}+\mathrm{EMB}$ 주 2희 4 개 월 또는 $\mathrm{INH}+\mathrm{SM} 4$ 개월 치료한 결과는(총 6 개월 치 로) 2 개월 투약에 균음전율 $96 \%$ 6개월 투약에 균음전 율 $98.5 \%$ 12개월 투약에 균음전율 $98.5 \%$ 로 6개월 투 약과 12 개월 투약결과는 동등한 균음전율이 나타났다. 이상과 같은 치로후 6 개월동안 관찰한 결과에 재발울 은 $15 \%$ 로 보고되었다.

4. 폐결핵의 REP투여에 3 가지 간헐요럽 임상적시험 (Dr. Blasi Italy)

$\mathrm{REP}+\mathrm{INH}$ 매일 4 주동안 치료하고 난후 REP $900 \mathrm{mg}$ 주1회 투약 또는 REP $600 \mathrm{mg}$ 주2회 투약하는 방법 역 시 효과가 좋다함.

5. REP의 부작용때에 침 강항체 (Dr. Stevens. Thailand) .

$\mathrm{REP}$ 부작용이 생긴환자 3 명에 대하여 혈청 (serum) 중에 3 Formyl-REP Formyl 유도체에 대한 침 강유 도체가 인정되었다. 이 유.도체를 피하내에 주사한결과 Arthus type 피내반응을 볼수있었다.

6. 노중 “REP 구루구로 나이드” (Dr. Nakagawa. Japan)

$\mathrm{REP}$ 를 경구투여한 사람의 뇨중에 물에 강한 침하 성을 보이는 새로운 $\mathrm{REP}$ 대사물질인 $\mathrm{REP}$ 의 Gluconide 카는 것을 알게됨.

7. A.B.O.식 혈액형 과 폐결핵(Dr.Viskum.Denmark). 34 개월간 고펜하겐 시내에서 신 발생한 결핵환자 98. $9 \%$ 에 대한 통계를 보뎐 결핵균 배양검사에 양성으로 나타난 환자는 기대치 보다 $\mathrm{O}$ 형이 많고 $\mathrm{A}$ 형이 적다. 균음성자에서는 정상분포로 나타났다고 함.

8. 한국의 척추결핵에 대하여 (Dr. Stott. England). $\mathrm{PAS}+\mathrm{INH}+\mathrm{SM}$ 과 $\mathrm{PAS}+\mathrm{INH}$ 를 장기간 치르한 결 과를 보고하였는데 두가지다 별차이가 없다고 하며 외 래환자를 “키부스자켓”을 사용한 결과 입원하여 안전 가료한 환자와 별차이가 없었다고 함.

9. 일본의 사킵병원 및 요양원에 입원 결핵환자 실태 (Dr. Kondo. Japan).

일본의 결핵요양소(협희산하)의 약 70 개의 사킵병원 과 요양소의 수천명의 외래환자 배경에 대하여 조사하 였다. 남자 총 $71.7 \%$ 여자 총 $28.3 \%$. 
입원당시의 상황

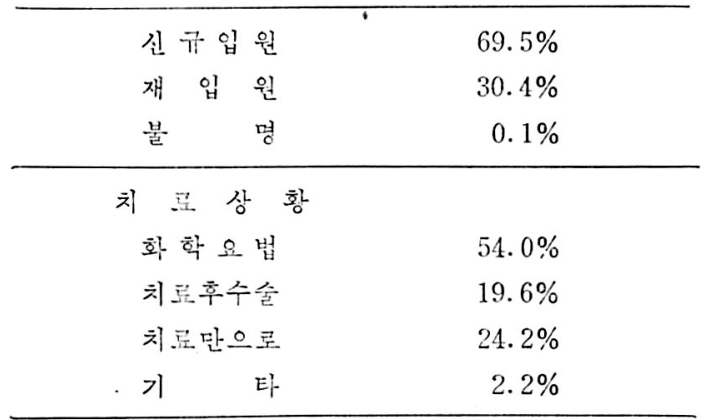

상기와 같이 치로한 결과 완치 $61 \%$, 중단 $31 \%$ 로 나 타났으나 중단환자 $31 \%$ 중에 개조사한결과 $50 \%$ 는 완 치되었다. 현재 일본에서는 ETA (1314)사용을 점차 감소하며 1960 년 대에는 $\mathrm{REP}$ 를 사용하지 돗하였으나 그후 1971 년에 $\mathrm{REP}$ 를사용환자는 $16.5 \%$ 로 점차 $\mathrm{REP}$ 를 사용하는 울이 높아 간다고 보고함.

10. 골 및 관절결핵의 진단 및 검사에 의한 확정

(Dr. Martini' Algeria)

골염 140 예 중에 골결핵 $30 \%$ 사지간절염 100 예중사 지 칸절 결핵 $60 \%$, 척추관절염 60 예중, 척추관절 결핵 $92 \%$, 이상퐈 간이 보고함.

11. INH간헌요법 (Dr. Vadasz. Hungary)

항가리에서는 INH를 주 2회 간헐요법이 가장 호과 가 좋은 결과롤 나타내고 있으며 1 일 1 회 요법이 1 일 수회 오법보다 호과가 더 좋다고 한다. 또 초기부터 $\mathrm{INH}$ 내성울은 $12.8 \%$ 이며 1 년이상 화학요법시 제약별 내성을은 다음과 같다. INH $60 \%, \mathrm{SM} 40 \%, \mathrm{~TB}, 40$ $\% 1321$ 41\%라고 보고핟.

12. 폐결핵 채치료시에 $\mathrm{REP}+\mathrm{EMB}$ 와의 간헐요법 비교 (Dr. Fraga. 부라질)

$\mathrm{REP} 600 \mathrm{mg}$ 을 매일 투악한 결과 간장장해 $7.3 \%$ 로 나타났으며 REP $1200 \mathrm{mg}$ 을 주 2회 투약한 결과는 간 장장해가 적었다고 한다. 부작용 중에는 피부질환, 자 반병, 위장계통, 호흡기계통과 같은 부작용이 나타났 다고 간단히 보고하였다.
결핵 및 호흡기질환 Vol. 21, No. 2. A pril 1974

() 이상과 같이 각국대표들이 발표한 개인연제는 1 백 여개의 연제를 발표하였으며 상기한 연제를 예를들어 보았다. 이회의에 참가한 국가대표들은 전반적으로 결 핵환자들의 대책문제를 가.지고 많이 논의하였다. 특히 결핵의 내인성 채연인지? 외인성 재감염인지를 가지 고 발표하고 토의했는데 각 국 학자들의 종합의견은. 결핵은 내인성 재연으로 보는 편이 대다수였다. 또한 대개의 국가에서 결핵치료제 중에서 $\mathrm{INH}, \mathrm{REP}$ 등을투. 약하는 과정에서 간헌요법을 시도하는 경향이 많으며 우리나라에서도 현재 간헐요법을 하고 계신 분들이 있 지마는 앞으로 더욱 장려하는 것도 바람직한 방법이라 생각한다. 고가약을 환자들에 게 호과적으로 치료하려 면 간헐요법을 하는것이 경제력이 없는 환자들의 실정 에 맞는다고 생각한다. 또한 결핵과 같이 장기간 치료. 를 요하는 질병을 퇴치하려면 의로보험제도를 서둘러 만들어야 될 것이며 조사연구 요원 및 결핵사업 의코. 인을 많이 육성하고 결핵에 대한 상식을 국민들에게 인식시키는 보건교육도 중오한 일이라고 본다. 현재하 고 있는 사업중의 하나인 예방접종 사업을 더욱 활발 하게 전개해 나가야 될줄 믿는다. 참고로 이회의에 참 석한 북한대표의 발표내용을 보면 결핵관리에 있어서 지역책임제를 실시한 경험과 성공한 예를 밝혔는데 북 한은 인구 5 천명 내지 1 만뎡 단위로 핵결간리를 위한 책읻자를 두고 있다고 말하고 출생아는 1 주일 이내에 $\mathrm{BCG}$ 를 접종하며 모든국민의 $90 \%$ 이상이 X-Ray 검진 을 받고, 치로율은 $98 \%$ 라는 허무맹랑한 과대 선전을 하면서 결핵단체에서 까지 정치적 선전을 늘어놓아 다 른 회원국 대표들르 부터 웃음꺼리가 되었다. 금번 개최된 제 22 차 국제항결핵 연맹회의에 참석한 우리나. 라 대포들이 예년보다 많이 참석하게 된것은 당국의 많은 배려와 협조로 이루어진 것이라 하겠으며 다른 희원국들도 우리나라의 결핵관리 실태를 이해했고 비 록 선진국보다는 결핵유병ㅇ율이 높으나 예산에 비추어 우리에 결핵사업은 잘 이루어지고 있는 것으로 인정을 받고있다. 